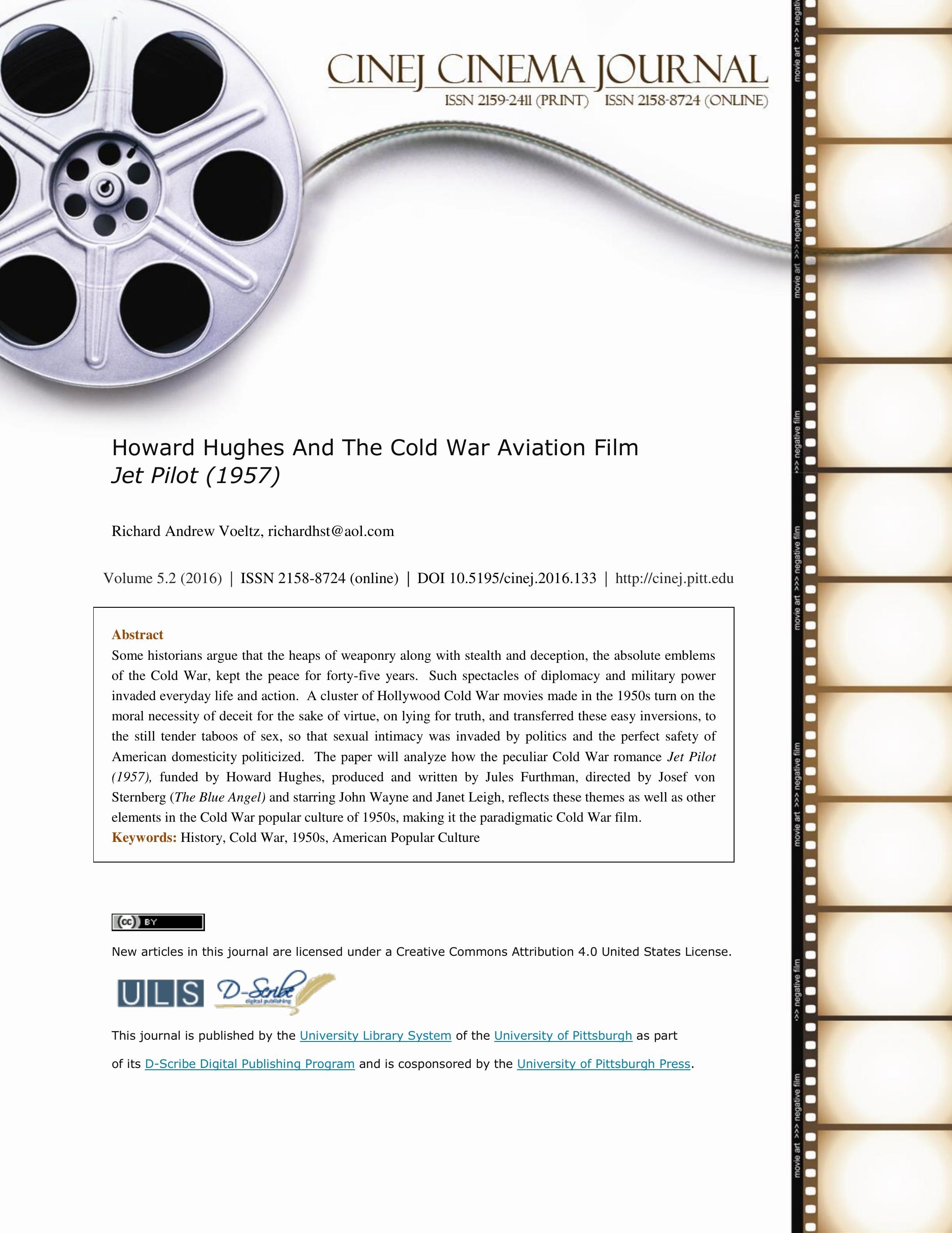




\section{Howard Hughes and The Cold War Aviation Film Jet Pilot (1957)}

\section{Richard Andrew Voeltz}

The film Jet Pilot (1957), easily subtitled as the "the Cold War gives way to Eros", remains an underappreciated gem of high camp from the era of the 1950s that offers unique insights into the eccentricities of Howard Hughes, as well as the nature of American Cold War cultural politics and society. This paper will reveal how sexual intimacy, consumerism, and technology became conflated with the perfect safety of an ideal American domestic life. Generally seen by reviewers as a major disappointment, it also intrigues today because of the involvement of the legendary and increasingly bizarre Howard Hughes as RKO producer from 1948 to 1955, who was known as the "The Spook" in Hollywood. ${ }^{2}$ His film Hell's Angels (1930) had set the standard for aerial action, and Jet Pilot includes the spectacular flying scenes of Chuck Yeager, first to break the sound barrier. Jules Furthman provided the tongue in cheek, comic script brimming with sexual double entendres. He would write one more script for the western Rio Bravo (1959) before retiring from film. He had previously penned The Outlaw (1943), Hughes' infamous take on Billy the Kid and Jane Russell's breasts. Josef von Sternberg of The Blue Angel (1930) with Marlene Dietrich fame provided partial direction for Jet Pilot, which starred John Wayne and Janet Leigh. Done in his declining years Jet Pilot was von Sternberg's first color film and his only comedy. After delivering his own cut of Jet Pilot, he went on to direct Hughes' Macao (1952) and the little viewed Anatahan (1953), before he retired from film.

This essential remake of Ninotchka (1939), a film that featured Greta Garbo as a cold, dedicated soviet agent who is melted by love and the hedonistic pleasures of Paris, with 
jet engine roar was plagued with production problems, personality disputes, and the perfectionism of producer Hughes as regards the aerial scenes. Hughes also constantly pursued Ms. Leigh romantically. John Wayne and von Sternberg hated each other. The plot of Jet Pilot seemed to lack seriousness during the Korean War as regards the communist threat, as it did also for its portrayal of typical stereotypes of Soviet-American relations, ideology, and gender during the 1950s Cold War Era. Jet Pilot had an initial budget of $\$ 2$ million dollars, very large for the time. The budget eventually hit $\$ 4$ million, but who knows how much Hughes finally put into the film. Initial filming begun in 1949 and was completed in seven weeks. 1950 was a pivotal year of rupture in the Cold War that made the decade one of fear and anti-communist hysteria. In 1949 Americans could still see themselves as invincible in the new, post-war world. The Soviets could be handled. But as Leslie A. Rose observed in The Cold War Comes to Main Street: America in 1950: "One year later, the United States had become another country", where optimism gave way to a "profound, embittered malaise" that still has not left Americans. ${ }^{3}$ Filming resumed and was not completed until May 1953. But then constant editing, more director changes, and more reshoots delayed the film's release until 1957, by which time not only had the mood of the country changed, but many of the aircraft and flying scenes were now dated. Hughes hired a second team to update aerial footage provided by the USAF and even brought back the actors seven years after initial filming had commenced. His biographer Richard Hack wrote that "John Wayne and Janet Leigh looked as if they had been stalled in time capsules, their youth standing in odd playback compared to their current films running in the theaters at the same time."4 In the interim several cast members had even died. Similar to his conversion of Hell's Angels to a "talkie", Hughes ordered that the film be reedited and reprocessed for the newly available wide-screen 
projection technology. ${ }^{5}$ Upon its release to movie houses in 1957 by Universal Pictures, which now had the rights to the film, Variety stated that the movie had been "kept under wraps by indie film-maker Howard Hughes for unstated (but much speculated upon) reasons." ${ }^{\text {Jet }}$ Pilot enjoyed less than stunning box office success. It lost millions. After its initial run Hughes got the rights to the film back, along with The Conqueror (1956), and then withdrew both films from circulation for over twenty years. In 1979, Universal acquired from Summa Corporation, the Hughes holding company, eight movies produced by Hughes for $\$ 1.5$ million dollars, including Jet Pilot and The Conqueror, perhaps John Wayne's worst picture-- (John Wayne as Genghis Khan?). Neither film had seen the light of day for years nor been released to television. As he slipped further and further into insanity, Hughes alone watched these two films for twenty years. Jet Pilot was his last and reportedly favorite film, one he watched repeatedly, along with the Cold War potboiler Ice Station Zebra (1968). Premiering on American television in October 1981, "Jet Pilot proved that the only way to enjoy the film was as a lamentable footnote in Sternberg's previously glorious career — and as high camp!" And as for the career of John Wayne it was “...even more embarrassing ....than Blood Alley, but no less propagandistic than Big Jim McLain" 7, two of Wayne's other anti-communist films. Jet Pilot was released on DVD in 2000 by Universal, and is now widely available on many Internet sites, in partial clips or in its entirety. ${ }^{8}$

Francois Truffaut who reviewed Jet Pilot in 1957, observed, “it isn't a likable film and it isn't inspired by any ideology....Still, amazingly enough, it is a successful, even beautiful film." Truffaut was one of the few reviewers who appreciated the good aerial shots and strong production values of the film, even if the plot looks positively unsophisticated today. "Wayne does his macho best as the colonel in charge of an Alaskan Air Force Base."10 
A Russian defector enters American air space and lands at the base. Colonel Jim Shannon (John Wayne) and his fellow officers are surprised to find that the pilot is a very attractive woman, Lieutenant Anna Marladovna (Janet Leigh). They fly to a fictional Palmer Field in California to meet with Major General Black (Jay C. Flippen) and Intelligence Agent George Rivers (Richard Rober) ), whether FBI or CIA is not clear, where Shannon is told that "Washington wants us to find out what interests her the most. " So amazingly they will let her fly advanced American jets. But Wayne soon learns to love his erstwhile enemy, "I hate your insides and vice versa". More so as he learns she will be deported, thus spoiling the budding romance. Love blossoms in Palm Springs, California. They then marry in Yuma, Arizona. "Do you know what they would do to you in Russia? They'd either shoot you or send you to the Uranium mines", replies Anna upon hearing of the light punishment Shannon will receive from his superiors for marrying the Soviet pilot in secret. Then it's discovered that Leigh is actually a Russian spy named Olga Orlief, one of their best in fact: "I understand she drove British intelligence absolutely crazy", exclaims Agent Rivers. This establishes the important Anna/Olga schism in the film. Anna represents the fun, freedom-loving pilot seduced by American abundance and John Wayne, while Olga represents the atavistic dark side of a regimented disciplined, patriotic Soviet operative and pilot. Inevitably Anna will win out over her double. Shannon agrees to pretend to defect to Russia with Anna/Olga to learn what he can about any weaknesses in the Soviet Air Force. While at a Soviet air base in Siberia that seems as sinister as a Boy Scout camp, Anna, now called Olga, learns how tyrannical the Soviet system is when she discovers that Shannon is being given a drug that will destroy his memory. After calmly shooting down two Soviet fighters ---“Good work, baby!-- she and Shannon (Wayne) fly back to the US in a stolen, top-secret Soviet jet. They settle down in 
Palm Springs, "where they eat enormous steaks, Leigh wiping away a streak of gravy from her face so Wayne can plant a final kiss on her pouting lips."11 "If only I could make my people realize things like this are more important than all the guns in the world, "Anna sighs. Rarely have fifties American films resorted to such carnivorous materialism as emblematic of the good luxurious life found in America, literally “...eating huge steaks, symbol for the American Way." 12 But food can serve as a potent metaphor. Anna (Olga) was completely flummoxed at first when told by Jim that there exists in Palm Springs more than one gigantic, juicy steak, and that in fact she can have one of her very own. James Powers of the Hollywood Reporter found the Palm Springs episode disturbing, representing a “....a frolicsome attitude about deadly situations....that is in questionable taste."13 Another reviewer upon the release of the film in 1957, remarked, “The symbols of American affluence are elegant nightgowns, sexy lingerie, and big steaks. It is no wonder then Leigh falls in love with John Wayne and Capitalism." 14 Variety wrote that, "The incongruity would appear less glaring if Jet Pilot were out to be a takeoff on secret agent stuff. But much of it is played straight."15 Moscow will never measure up to Palm Springs, not to speak of Disneyland or Playboy magazine. Walt Disney would bring together the elements of magic, sentiment, leisure, and consumer marketing that helped to forge a vision of the American Dream. Hugh Hefner brought the trend to its apex. Steven Watts writes, "More than any other single figure in this latter era, he has symbolized the combination of sexual liberation, material affluence, and personal self-fulfillment that characterizes the modern American dream."16 Anna with Jim can now realize that American dream of domestic happiness.

When Howard Hughes purchased the rights to a story called Jet Pilot he certainly envisioned a jet aged Hell's Angels. He wanted to tell a similar story about Cold War flyers. 
For the spectacular aerial footage that Hughes demanded he sent film crews all over the country. He had the full cooperation of the Air Force who supplied him with their top pilots. Hughes spared no expense in the cinematography. As Randy Roberts and James Olson write:

They shot footage in California, Nevada, and Colorado, spending weeks and hundreds of thousands of dollars on the ground because the clouds were not right. They traveled to Fargo, North Dakota, then back to Denver. They encountered snowstorms in Great Falls, Montana, and Rapid City, South Dakota. ... One location blended with the next.... Great Falls, Reno, Las Vegas, Oakland, Burbank, Rapid City, Toulonne Meadows, Mount Shasta, Mount Lassen, Sacramento. Weeks became months. ${ }^{17}$

One man almost burned to death in a B-29 fire. Chuck Yeager was nearly killed when his F-86 lost power and he had to crash land. Biographer Charles Higham wrote that Hughes "went crazy...now dispatching second and third camera crews in zigzags across thousands of miles, looking for fuckable clouds." "18 By January 1951, Hughes had shot 150,000 feet of film, enough for a film twenty-four hours in length, ten times more than he needed for the final picture. Stunt pilot Paul Mantz shot stunning sequences that were mostly left on the cutting room floor owing to Hughes' perfectionism or out of date aircraft by $1957 .{ }^{19}$ Right up until the end Hughes continued his search for the perfect jet movie using his contacts in the aviation industry and the Air Force. ${ }^{20}$ Hughes finally sold RKO in 1955, but he had left his mark with the ludicrous The Conqueror, starring John Wayne as Genghis Khan opposite Hughes' one time girl friend Susan Hayward. Jet Pilot was released in 1957 by Universal Pictures — some eight years after production began. It was ridiculed for its obsolete depiction of aviation and cornball plot, and dubbed "Hughes' biggest RKO failure. ${ }^{21}$ Whatever it finally turned out to be it was not the film homage to the jet age that Howard Hughes had initially envisioned. 
Getting the clouds right was not the only problem with the production. Hughes micromanaged not just the flying scenes but also obsessed over getting the right hairstyles and cloths for Wayne and Leigh. Director Josef von Sternberg, admittedly past his prime, was hired, fired, rehired, and re-fired. Initially he was told by Hughes and Furthman to keep the focus on the flying sequences. ${ }^{22}$ A veritable "Conga line" of directors followed him, including Hughes himself, as well as Peter Godfrey, Jules Furthman, Nicholas Ray, Don Siegel, and Paul Cochrane. In his autobiography, von Sternberg describes his ordeal:

I again accepted a cart before the horse assignment, and returned to the quagmire of Hollywood, my apprehensions being lulled by what seemed to an extremely favorable outlook. I was asked to make a film to be called Jet Pilot for a man for whom I had considerable respect---as a flyer....My labors lasted some seven weeks, not counting the many weeks of preparing the film and editing it, with which no one interfered at the time....My name is on the film as director, and there are other names mentioned also to which are given credit for functions that were just as shadowy, but the names of all those who had a finger in that celluloid pie are mercifully omitted. The pastry featured John Wayne as the pilot, and Janet Leigh as a Russian flyer, and the crust was the playful affair between the two, ending on the happy note of steak being consumed, demonstrating that our way of life was superior. $^{23}$

Von Sternberg however was not without fault. Known for his arrogance, rudeness, and endless rehearsals, John Wayne told Leigh that if he let his temper get the better of him, "I'd kill the S.O.B." Roberts and Olson write, "Between von Sternberg and Hughes there seemed no end to the petty nonsense, and the project, like a bad faucet that leaked dollars, continued to drip." 24 Janet Leigh remembers the film and its director: "He had marvelous effects... and he did things that were provocative without being openly displayed, which to me is always more interesting. Von Sternberg was really better than I wanted to admit, because I didn't particularly like 
him... he had the most infuriating way of saying something". ${ }^{25}$ An interesting sidebar to the whole fiasco was Hughes's fascination with Janet Leigh. As Charles Higham relates it:

He called Jules Furthman into his office and asked him to make sure that Janet Leigh would "marry Mr. Hughes at the earliest possible opportunity. Knowing that Hughes was already "married" to Terry Moore, if only by a captain at sea, Furthman didn't ask the question. Furthermore, she was dating MGM executive Arthur Loew. ${ }^{26}$

In an interview Janet Leigh claims that Hughes had bugged her phone and was monitoring her activities, something he was famous for with all his women. She still refused to go out with him, which meant her career languished at RKO. Could part of the explanation for holding back Jet Pilot be based upon something as frivolous as Janet Leigh spurring the advances of Howard Hughes? ${ }^{27}$

Sometimes the analysis of a film and its relationship to the culture around it devolves into something quite simple. This is the case with Jet Pilot. Roberts and Olson certainly got it right when they said of the film, "It was clear that Hughes was determined to use the film to explore three of his obsessions: anticommunism, women's breasts, and aviation."28 As for his anti-communism, Richard M. Nixon, then junior senator from California, went so far as to insert in the Congressional Record that Hughes had sought "to establish the principle that no industry need support those whose loyalty to this country is questionable, and by public statement he has rallied the support of right thinking people across the land behind his campaign to get the Reds out of the motion picture industry." 29 Hughes gave a speech before Hollywood Post 43 of the American Legion in which he stated without the slightest doubt that "...there are a substantial number of people in the motion picture industry who follow the party line." In 1952 Hughes spoke about "a Goddamn Commie" who 
worked for him at RKO. Hughes was lauded by the Los Angeles City Council for his "intestinal fortitude" in a "ceaseless battle against Communist infiltration in business and government." Frank C. Hilton, the commander-in-chief of the Veterans of Foreign Wars, praised him for his vigilance against “...men and women of subversive tendencies and particularly those who have been associated with Communist front organizations" ${ }^{30}$. The history of the 1951 RKO film The Man He Found might be very instructive. Made at about the same time as Jet Pilot and directed by William Cameron Menzies, the film originally dealt with a demonic Adolf Hitler hiding out in the Wisconsin backwoods with a group of fanatical followers plotting an attack against the United States. After the film failed miserably in its initial marketing, Hitler and the Nazis were all deleted and replaced with communists. The film was then released under the new title The Whip Hand. Motivated by Hughes's anticommunism and the desire to exploit American paranoia of communism, Nazism had become redundant as the arch-fiend at $\mathrm{RKO}{ }^{31}$

In the film Jet Pilot itself Hughes allowed very blunt but not vicious propaganda references to the many shortcomings of the Soviet system and communism. When Shannon (Wayne) finds a cigarette lighter on Anna (Leigh), he quips, "Wow! One that works!, one of many references to the deficiencies of Soviet consumer products. In Palm Springs Anna calculated that four Russian families would fit into their hotel room. Before "defecting" to Russia, Anna/Olga tells Shannon about Russian vodka. He comes back with, "That's ok if you don't mind Russian breath---Knocks everything over within fifteen feet." While Shannon is in Russia the conditions are obviously very primitive, with door knobs falling off, etc., all leading him to lament how he misses "...American cigarettes and coffee." Olga's Soviet military handler General Langard seems to agree exclaiming at one point, "What am I saying refusing 
an American cigarette!". Shannon complains about the food too, "Blintzes again!". Much of this sounds like recycled World War II dialog. And in fact Shannon relates how he got drunk and sang songs with the Soviets during the war. Then they turned bad. While at the Soviet base Anna points out a famous woman sniper from that war, now doing hard labor. Shannon asks if that is the way the Soviets treat heroes. "Rumor has it that she started shooting Russians", Olga/Anna solemnly informs him. Phrases such as "You Yankee Gangster", or references to your "dirty rotten capitalist country" are heard, but mostly delivered for laughs or in frustration. The Soviets do get serious treatment however when they administer an Orwellian serum to Shannon that in the words of an American intelligence officer "makes you forget that you forgot." Major General Black intones that they will use the same drug as they used on the hapless Hungarian Catholic Cardinal Joseph Mindszenty, who at a show trial in 1948 pleaded guilty to Soviet charges, leading to the suspicion that he had been drugged. This all led to the belief that the Soviets could completely control their victims through drugs or "brain-washing", a word first used in 1950, but destined to become a cliché in Cold War rhetoric and Hollywood movies. ${ }^{32}$ The Soviets are clearly a nasty, unprincipled adversary. Agent Rivers tells Anna/Olga that it is, “...refreshing to hear a commie talk about honor." But at the Soviet base in Siberia, Olga's cartoonish bad guy superior's, including the perennial character comic actor Hans Conreid, come across as defective and buffoonish enemies, who cannot even figure out the difference between an jet ejection handle and a seat adjustment lever, leading to the expected rapid exit of a Soviet handler, allowing Anna to escape in the jet. The Soviets are easily overwhelmed by American intelligence, ingenuity, technical superiority, capitalism, and freedom of choice material consumerism. 
His love of flight and aviation technology comes through even in the truncated, severely edited Universal release of 1957. One only wonders what he edited out or never included. ${ }^{33}$ Critical opinion of the flying sequences and the film in general have changed over the years. Critic Mark Spratt gave the flying sequences and Jet Pilot in general a very positive review when a $16 \mathrm{~mm}$ print was reissued by the British Film Institute in 1982. A biography of Paul Mantz, the principle stunt pilot and cameraman for the film, came out in $1967 .^{34}$ And as Brandon Hookway provocatively notes, “...it is in the privileged site of man-machine interaction - the cockpit - that we find the prototype of postwar space." Hookway applies architectural scholarship to the Cold War era to argue that it caused enormous spatial reorganizations and transformations, creating nothing short of a new American culture. And nothing was more crucial in that transformation of the man-machine relationship than aviation, symbolized by the space of the "cock-pit." 35 While Shannon (Wayne) poses as a defector he gets assigned to help test new Soviet aircraft, especially the "Soviet parasite fighter" while revealing to the Soviets American air capabilities. He does indeed learn much more about Soviet tactics and aircraft while of course revealing only outdated information to his hosts. In fact by the time the film was released most of the aircraft were really outdated. The "Soviet parasite fighter" that Shannon flies is actually the Bell $\mathrm{X}-1$, the first supersonic aircraft in the world, piloted by Chuck Yeager. The footage of the "Soviet parasite fighter and mother ship is the exact same footage used in the movie The Right Stuff (1983) of a B-29 taking off for the first supersonic flight. The "mother ship" for the "Soviet parasite fighter" is actually a Boeing B-29. The Russians had in fact reversed engineered the B-29 from three planes that made emergency landings in Russia during World War II and built hundreds of them as the Tupolev Tu-4 "BULL". When Anna defects her Yak-12 is really a black painted T-33 Shooting Star. A 
Northrup F-89 Scorpion appears near the end of the film but most of the flying sequences feature the very out-dated by 1957 F- 86 Sabre Jet. In one scene obviously done in 1950 Shannon and Anna fly an obsolete F-94 Starfire jet to test a radar night approach intercept of a propeller driven B-36 bomber, truly a relic of the very early Cold War. Back on the ground after this incident, Anna exclaims, "Oh you Americans!" "What's the matter with us?", Shannon responds. Anna answers with, "You are utterly antagonistic to any form of regimentation on the ground but in the air you accept it in the most abject manner." "You got to admit it works pretty good", Shannon retorts. "That's what puzzles me", concludes Anna. Here we have perfectly expressed the American ideal of freedom in every phase of civil society, coupled with technological discipline and superiority. On Armed Forces Day, a creation of the Cold War, 1950 eight B-36's from Carswell Air Base overflew the capital of each state in the Union. Much of the filming for Jet Pilot was done at Edwards Air Force Base, the stand in for Palmer Field and George Air Force Base outside of Victorville, California, which became the Soviet airbase in Siberia. ${ }^{36}$ The B-45 Tornado was used as the camera aircraft for the flying sequences at Edwards. The aerial sequences in Jet Pilot lack the masculine, aggressive jet "jock" scenes found in the late Cold War, Reagan era film Top Gun (1986), although some of the competiveness remains. The fact that so much of the Cold War was defined by heaps of current military hardware and dazzling technology meant that the dated airplanes turned off audiences, and it certainly turned off Howard Hughes who continually tried to update the aerial sequences. At the time of Jet Pilot's release Anthony Mann's wide-screen Strategic Air Command (1955) came out with almost identical aerial scenes. The film also featured the newer B-47 Stratojet piloted by the popular actor Jimmy Stewart. And even the B-movie Drive-In classic Fiend Without a Face (1958) featured aerial 
shots of the brand new B-52 bomber. For John Wayne Jet Pilot constituted just one of four aviation films that he did in rapid succession, the others being Flying Leathernecks (1951), Island in the Sky (1953) and The High and the Mighty (1954).

So Jet Pilot remains a fascinating example of Hughes' interests, obsessions, eccentricities, and passions, from his anti-communism to the latest feats of aircraft engineering. But nothing surpassed his passion for, and obsession with, the engineering of Janet Leigh's breasts. Remember the care with which he fussed over Jane Russell's cleavage in The Outlaw, as well as the subsequent battle with censors. After all the opening credits thunder, "Starring John Wayne, Janet Leigh (or more appropriately Janet Leigh's Knockers)” and the Unites States Air Force." The poster for Jet Pilot promised "JET FLAME ACTION, JET-HOT THRILLS, Exploding with all the power of the Jet-Age...with all the passion of a daring love story." 37 As the biographers of John Wayne put it, "Throughout the film Janet Leigh wears bras that look as if they had been built out of reinforced concrete and if needed could be used as weapons." 38 Certainly the style for the 1950s, but nonetheless they provoked the ire of the Production Code Administration which warned the producers of the film: “....The Production Code makes it mandatory that the intimate parts of the body-specifically, the breasts of women-be fully covered at all times. Any compromise with this regulation will compel use to withhold approval of your picture." Code administrator Joseph Breen also warned that a line spoken by Major Rexford (Paul Fix) __'I love all kinds of equipment"---would be “unacceptable if it refers to Anna's breasts. His look accompanying this line should not be leering or leacherous." 39

In fact all attention is focused on Leigh, an improbably beautiful Soviet pilot/ agent who looks good even today whether wearing a bathing suit at the pool in Palm Springs or a 
flight suit in a Soviet jet shooting down her own countrymen. Leigh as Anna/Olga may look great, but sounds ridiculous, not even attempting to speak in a Russian accent. Why should she? Her command of English is perfect. Leigh had in fact just appeared as a German/Russian ballerina in The Red Danube (1949), a more conventional, heavy-handed anti-communist film. Her linguistic naïvete comes out when she does not understand the meaning of "baloney" or "cupcake", as in "You silly Siberian cupcake", but seems to know when somebody is being made a "Chump". Jet Pilot serves up some pretty daffy sexual innuendo that reveals just how much sexual intimacy had been invaded by politics during the Cold War, thus challenging the safety of American sexuality and domesticity, while at the same time confirming it. This foreign object of desire crashes into America with a three word salute---“A woman...A lady...A dame", while jets whoosh overhead. The ubiquitous jet "whoosh" always seems to sound the same. In an early scene, Lieutenant Anna Marladovna does a modified strip-tease as Shannon attempts to search her, and then showers while she sings the World War II army tune The Song of the Red Army, all to the punctuation of more whooshing jets. All this erotic activity prompts Shannon to exclaim, "This might be a new form of propaganda. Maybe they really want to win friends and influence people." Muted sexual double-entendre's abound, most of which are at least a couple of generations removed from comprehension let alone appreciation by college students today, as well as by most viewers of the film. Some admittedly can be taunting: "Lady, you are the Peruvian donuts.” Paul Fix as Shannon's buddy Major Rexford quips with a straight face when asked if she had any fuel left, "The bottom of her tank is still damp." When asked by his superior to seduce his erstwhile enemy he responds angrily, "I'm a jet man, not a gigolo!". A whole sequence of gags spin out of a comment about “stuffed birds": "So, you're a taxidermist?", "You are pretty well stuffed yourself baby!", etc. 
While looking at swim suits for Anna, Shannon jokes, "Both of our countries want to uplift the masses." Anna/Olga has breasts that resemble missile nose cones. Anna/Olga buys a hat and exclaims, "It's perfectly silly and I adore it," her regimented demeanor now melting. In a more intellectual exchange between the two, Anna says, "Love is the same as religion. They make you forget your duty." To which Shannon responds: "Love! Baby, you were made for it!" In another scene Anna/Olga tells Shannon, "One minute I want to kill you, the next minute, I want to kiss you and kiss you." Anna/Olga then fumes, "So, I'm attractive to you in every way except politically." "That's about it", he tersely replies, making it clear that sexual and political seduction remain separate for him. To seal the deal, Shannon then refers to Anna/Olga as his "Soviet tootsie roll." Howard Hughes happily conflates his passions for sex and aviation technology in the scenes of Anna and Shannon flying two jets together. In fact these scenes mark the high point of the entire film, and are greatly underappreciated. While flying together Shannon radios, "Say a prayer!" To which Anna/Olga responds: "I don’t believe in that stuff!" Shannon retorts with, "Then forget about flying." All of these aerial scenes were lovingly photographed against a background of large breast-like cumulus clouds, something that Hughes insisted upon and spared no expense to obtain. Against this fluffy, erotic background the two jets dive, climb, turn, bank, roll, together, or with one on top, then another. Shannon executes a roll over Anna's jet to her response of "Whoa! How'd you do that!". Not your typical pilot response. The radio chatter between the two, "This is A for Anna", "flame-out", "your rear is hot", "Is your compressor working?", "Hold the stick tight", erotic-mechanically simulate the sexual act as effectively as the famous Dadaist paintings by Francis Picabia or Marcel Duchamp. This erotic aerial ballet served to break down the differences between communism 
and capitalism. Back on the ground after the nighttime intercept of the B-36 when they do actually physically kiss, Shannon remarks "a perfect example of teamwork".

But beyond the pulchritude of Miss Leigh's breasts, Jet Pilot also provides a revealing portrait of American cold war culture and politics. Overlooking much of Hughes' endless tinkering with the film or his fascination with Ms. Leigh, screenwriter Furthman believed that the movie's release was delayed because, "we kid the Russian situation, and the tone was not quite right to use during the Korean War."40 When the film finally came out in 1957 he also had doubts that the audiences would accept outdated fashions. ${ }^{41}$ Critics at the time of its release noticed this light treatment. It is “....a dog eared copy of Film Fun magazine, one of the early cheesecake books", wrote Dick Williams of the Mirror News in September, 1957. The Los Angeles Times described the film as "a make believe juvenile fantasy." The New York Times wrote that the film was so silly, that "we blush to tell you what is its story.... the performers play their "quaint role like a couple of fumbling kids." 42 Aside from some fluffy attacks on the inadequacies of the Soviet system, the films ideological message is diluted:

The difference between capitalism and communism, the movie implies, is the difference between a thick steak and a blintz. After Anna sees Palm Springs, samples the food and fashions of America, and witnesses the material advantages of the United States, she can no longer tolerate the drab Soviet life. As for Shannon, Anna's body overcomes his disdain for her beliefs.... he discovers that beneath every hardened Communist is a budding capitalist. $^{43}$

Shannon's attraction to Anna (Olga) might be termed a Soviet attempt at deception meets Hugh Hefner's American male Playboy fantasy centerfold -lifestyle. In 1953, Hugh Hefner marketed the first edition of Playboy, promoting a hedonistic philosophy of sex, that sex is something recreational and entertaining, and not confined solely to marriage. "The playmate of the month 
was a political proclamation. Playboy wanted to realize the American dream.... the idea was to transform the next-door neighbor girl into a sex symbol... meaning that even nice girls enjoyed sex." 44 The ability to have choices of consumer items, including the commodity of the next-door neighbor girl, separated the United States from the gray, drab, uniform existence of communistic societies. That ability to choose defined the good life. "In many ways, Playboy embodied this ideological impulse.... Playboy insisted that adoption of a pleasure ethic would strengthen America in its struggle with communism." 45 However as the KGB quickly discovered in recruiting Americans as Soviet agents hedonism and pleasure could be a two-way street. Appeals to ideology, particularly after the 1950s, usually got them nowhere with Americans, but money, sex, and pleasure, oh yes, that is another story.

The Russian Anna/Olga offers Jim Shannon a version of the American Dream: a woman who loves America and its consumer society, and is well stacked too. "Jim and Anna" can now settle down in their suburban home in Palm Springs, California and live the good suburban life of barbecues, cocktail parties, nice lawns, real or fake, swimming pools, and material comfort, where Anna parades around looking sexy in a swimsuit and Shannon struts like a peacock glad to be living the American Dream. Despite the good versus bad simplistic nature of the film, this message should have resonated with Americans. But Jet Pilot could not get a break. Perceived as being too light on the Soviets when it was first produced in 1950 during the Korean War and in the immediate aftermath of the Soviet atomic bomb and the "loss" of China, by 1957 the film's comedic, light-hearted approach to sex and luxury came in for ridicule as being a "Rover Boys approach to serious problems", a "make believe juvenile fantasy" in "questionable taste" with a "corny approach to sex." 46 The quest for happiness, 
self-fulfillment, material abundance, romance, and sexual gratification remained paramount in the 1950s but not without accompanying anxieties.

Howard Hughes meant Jet Pilot to be a paean to the jet age mixed with some light anti-communism, and cute romance. The film initially started production in $1949-1950$, but was not released until 1957. 1950 marked a pivotal turning point in the Cold War for America. Prior to that year the country could still bask in the glow of victory in World War II, confident that the possession of the Atomic Bomb coupled with the new, mighty power of the U.S Air Force, could counter any potential Soviet theat. But after 1950 all that changed with the fall of China to communism, the Soviet A-Bomb, loyalty oaths, the rise of Senator Joe McCarthy and the Korean War, all leading to paranoia about communism, coupled with a gripping, irrational fear of the Soviet Union. Or as the French philosopher Jean-Paul Sartre put it to the Americans in regard to the execution of Julius and Ethel Rosenberg, the "Atomic Spies" in 1953, "magic, witch hunts, auto-da -fe sacrifices---we are here getting to the point: your country is sick with fear." ${ }^{47}$ The original script for Jet Pilot relied on old pre-war Ninotchka or World War II tropes about life in the Soviet Union where regimentation, ideological fervor, and scarcity prevailed, compared to the abundance and freedom found in America, even during the dark days of that war. But the Soviet people were not portrayed as complete fiends. After 1950 nothing seemed very funny about the Soviets. Jules Furthman felt that the film simply had too light an anti-Soviet tone for the time of the Korean War. Already plagued by the micromanagement of Howard Hughes, his obsession with the flying stunts, having the most advanced American aircraft in the film, director changes, and personality conflicts, Jet Pilot remained in the RKO storage vaults. Then after more tinkering by Hughes, reshooting, and with new aerial scenes inserted, Universal finally premiered the film in 1957, sensing that a 
break in the Cold War, along with the earlier release of two similar Cold War Ninotchka-like romantic comedies Iron Petticoat (1956) and Silk Stockings, (1957) made the timing auspicious. But in 1957 the Soviets launched Sputnik sending America into a tailspin as regards being tough and dedicated enough to compete with the Soviets. So now the "let them eat big, juicy steaks, washed down with Tom Collins cocktails while relaxing around the pool in Palm Springs in sexy swim suits" message of the film seemed jarringly out of synch with a putative America now dedicated to solving math problems and doing physics, rather than pursuing mindless excess. Out of date aircraft did not help to reassure Americans either. The film flopped along with the Ford Edsel. The production and release history of Jet Pilot marks a transition in the treatment of the Soviet Union by Hollywood, moving from the World War II confident America model, to one of a fearful America that depicted the Soviets as implacable, totally evil force. Jet Pilot also marks the break between the old romance/defection/escape plot with what Tony Shaw terms Hollywood's “...full scale war on international communism from the late 1940 s to the early 1960 s". ${ }^{48}$ Here we have a movement from a Soviet female spy seduced by John Wayne, bathing suits and steaks, to Nightmare in Red (TV, 1956), where communism threatens the very sanctity of the American family and values. Cold War American images of the Soviets and communism had indeed changed, but not for the last time in the history of that conflict. ${ }^{49}$

The film Jet Pilot helps scholars to understand the cultural dynamics of the Cold War, as well as the eccentricities of Howard Hughes. Jet Pilot has its flaws, and cannot be considered in any sense a "masterpiece" of cinema, yet the film contains a level of humor that makes it watchable even today, as opposed to more strident, ideologically based Cold War features. If "camp" can be defined as an aesthetic sensibility that views something as being so 
exaggerated, even ridiculous, that it has a perversely sophisticated appeal, then Howard Hughes' Jet Pilot qualifies as a gem of high camp. The notion that an object of popular culture can be enjoyed and appreciated by a sophisticated sensibility is nothing new in scholarly analysis today. Truffaut called Jet Pilot simply a “...successful, even beautiful film.”50 Film critic Fernando F. Croce even compares the film to the work of the great French filmmaker Jean-Luc Godard, who as “...one of the few to have gotten the humor of Josef von Sternberg's 'comedy in close-up', had Belmondo and Seberg voice the punch line under the sheets in $A$ Bout de Soffle ( Breathless , 1960), "We're improving international relations"”. ${ }^{51}$ Mark A. Hasan in a review of the German DVD release (2007) complains that Jet Pilot continues to be treated by Universal “...like a poverty Row B movie" and "deserves a little respect." 52 The plot is admittedly thin, and at times, even dull. But Furthman's script sets a perfect tone with an exaggerated, unrelenting sexual banter, innuendo, and double entendres, that makes what seems like a serious film unintentionally hilarious. Or was it intentionally a spoof of itself? This is not a serious film at all, but rather tongue-in-cheek, and that is the best way to view the film. For many different reasons, modern viewers will find it funny, and for other reasons than they might laugh at Nightmare in Red, which seems hopelessly out of touch today. Beyond just von Sternberg fans and aviation buffs, what really makes Jet Pilot watchable now, is the over the top depiction of American consumerism and the carnivorous seduction of Anna/Olga. Indeed, while fleeing with Shannon, Olga ultimately decides while literally in the cockpit to betray her country and defect to the United States by invoking the memory of "Anna and Jim", and of eating, big juicy steaks in Palm Springs, with the prospect of more to come. Olga the Soviet officer has been transformed into Anna, the ideal American trophy wife. Not only do Americans shop till they drop, but they also eat till they drop. Very rarely have the four 
American passions, for sex, shopping, food, and technology (exactly what Hugh Hefner wanted to package in Playboy) been so unashamedly put forward as to what constitutes the American way of life, regardless of any Cold War context of an out- dated anti-communism. With Howard Hughes' conflation of sex with aircraft engineering added into the mix, you have a humorous, campy portrait of American culture in the 1950s that still rings true today. Jet Pilot with its vivid portrayal American material abundance, technology and consumerism would indeed eventually prove fatal for communism in the Soviet Union and the Eastern Bloc countries. The "All-American" ending found in Jet Pilot thus becomes the "All-American" ending of the Cold War.

\section{END NOTES}

${ }^{1}$ Fernando F. Croce, Jet Pilot (Josef von Sternberg/ U.S., 1957), p. 1. http://www.cinepassion.org/Reviews/j/JetPilot.html. Accessed 6/13/2012.

${ }^{2}$ John Baxter, The Cinema of Josef von Sternberg: The International Film Guide Series, New York: A.S. Barnes \& Co., 1971, p. 162.

${ }^{3}$ Lisle A. Rose in The Cold War Comes to Main Street: American in 1950, Lawrence, KS: Kansas University Press, 1999, p.6. David Fried in The Russians are Coming! The Russians are Coming!, New York and Oxford: Oxford University Press, 1998 focuses on the activism, public spectacles and pageantry that underlie the most colorful Cold War notions of American culture before the emergence of the counterculture in the 1960s. For a discussion of nuclear-age films and American culture in general see Paul Boyer By the Bomb's Early Light: American Thought and Culture at the Dawn of the Atomic Age, New York: Pantheon Books, 1985; reissued, Chapel Hill, University of North Carolina Press, 1994. For a very comprehensive if conventional and popular overview of the social, economic, political, and cultural history of the Cold War 1950s see David Halbertstam, The Fifties, New York: Villard Books, 1993 as well as the accompanying VHS/DVD 5 part series, The Fifties, The History Channel, A\& E Television Network Entertainment, 1997. 
For a great, entertaining collage of the sights and sounds of the 1950s go to

http://www.oldfortyfives.com/TakeMeBackToTheFifties.htm. Accessed 2/10/ 2013.

${ }^{4}$ Richard Hack, Hughes, The Private Diaries, Memos, and Letters, Beverly Hills, CA: Phoenix Books and Audio, 2007, p. 199.

${ }^{5}$ Harold Robinson, Russians in Hollywood, Hollywood's Russians, Biography of an Image, Lebanon, N.H.: Northeastern University Press, 2007, p. 172.

6 “Jet Pilot", Vareity, January 1, 1957. http://www.vareity.comstory.asp?1=story\&r=VE1117792145\&c=31. p. 1. Accessed 10/20/2012. Donald L. Barlett and James B. Steele, Howard Hughes: His Life and Madness, New York: W.W. Norton \& Company, 2004, p. 168.

7 “Jet Pilot”, Emmanuel Levy, Cinema 24/7, http://www.emanuellevy.com/search/details.cfm?id+2909. Accessed 3/16/2012. For Big Jim McClain see Ron Briley, "John Wayne and Big Jim McLain (1952): The Duke's Cold War Legacy”, Film and History, Vol. 3, No. 1, 2001, pp. 28-33. Barlett and Steele, p. 168.

${ }^{8}$ Mark A. Hasan, "DVD—Jet Pilot (1950/1957)—KQEK-Film on DVD, http://www.kqek.com/dvdreviews/j21/3538Jet Pilot/1957.htm. p. 1. Accessed 6/15/2012. Jet Pilot, GoodTimes Home Video Corporation,1 hour 52 minutes, 2000. In 2006 Universal re-released the film as part of a five-film DVD Box Set. A 2 PAL version released by KOCH Media (Germany) in 2007 contains a 24 page booklet with German liner notes by Sascha Westphal which provides a precise chronicle of the film, the era in which it was made, Hughes' tenure at RKO, and the problem in presenting the best screen ratio to present the film. The Jet Pilot production files, exhaustively detailed, are at the UCLA Research Library.

${ }^{9}$ Jeffrey M. Anderson, "Communist Plot", Combustible Celluloid, http://www.combustiblecelluloid.com/jetpilot.shtml. Accessed 3/16/2012.

10 “Jet Pilot: Review”, TV Guide, http://movies.tvguide.com/jet-pilot/review/102739. Accessed 10/22/2012.

${ }^{11}$ Ibid.

${ }^{12}$ Baxter, p. 164. For an entertaining discussion of food as metaphor in the 1950s-“Americans were what they ate"--(p.240) see Karel Ann Marling, As Seen on TV: The Visual Culture of Everyday Life in the 1950s, "Chapter 6, Betty Crocker's Picture Cook Book: The Aesthetics of Food in the 1950s", Cambridge, MA: Harvard university Press, 1994.

${ }^{13}$ Emanuel Levy, "Jet Pilot".

${ }^{14}$ Ibid.

15 "Jet Pilot", Variety.

16 See Marling, Chapter 3, "Disneyland, 1955: The Place That Was Also a TV Show", Steven Watts, The Magic Kingdom: Walt Disney and the American Way of Life, New York: John Wiley and Sons, 1997. Steven Watts, Mr. Playboy: Hugh Hefner and the American Dream, New York: John Wiley and Sons, 2008, p. 452.

${ }^{17}$ Randy Roberts and James S. Olson, John Wayne American, New York: The Free Press, 1996, p. 352. 
${ }^{18}$ Ibid.

${ }^{19}$ Hack, p. 199.

${ }^{20}$ Roberts and Olson, p. 353.

${ }^{21}$ Pat A. Boeske and Peter Harry Brown, Howard Hughes, The Untold Story, New York: DaCapo Press, 2004, pp.282, 168.

22 Baxter, p. 163.

${ }^{23}$ Josef von Sternberg, Fun in a Chinese Laundry, San Francisco: Mercury House, 1965, pp. 281-282.

${ }^{24}$ Roberts and Olson, p. 352.

${ }^{25}$ Baxter,pp 165- 166.

${ }^{26}$ Charles Higham, Howard Hughes, The Secret Life, New York: St. Martin's Griffin, 2004, p. 145.

${ }^{27}$ Interview with Janet Leigh, Howard Hughes: His Women and his Movies. DVD, 55 minutes, New York: Mesmirize Studios, 1999. Martin Scorsese's DVD biopic of Howard Hughes The Aviator (2004) which focuses on his Obsessive-Compulsive disorder does not mention Jet Pilot but has an accompanying DVD with many useful special features about The Aviator as well as documentaries dealing with Hughes. Burbank: Warner Home Video, Inc. 2005.

${ }^{28}$ Roberts and Olson, p. 351.

${ }^{29}$ Hack, p. 206.

${ }^{30}$ Ibid., pp. 204, 206.

${ }^{31}$ Gavriel D. Rosenfeld, The World Hitler Never Made: Alternative History and the Memory of Nazism, Cambridge and New York: Cambridge University Press, 2000, p. 211.

32 Susan L. Carruthers, Cold War Captives: Imprisonment, Escape, and Brainwashing, Berkeley and Los Angeles: University of California Press, 2009, pp. 83, 136-139, 154.

${ }^{33}$ For a fuller discussion of aviation and cinema see Michael Paris, From the Wright brothers to Top Gun: Aviation, Nationalism and Popular Cinema, Manchester and New York: Manchester University Press, 1995, James Farmer, Celluloid Wings, Blue Ridge Summit, PA, 1984, Stephen Pendo, Aviation in Cinema, New York, 1985, Bruce Orris, When Hollywood Ruled the Skies, Hawthorne, CA, 1984 and Robert Wohl, The Spectacle of Flight, Aviation and the Western Imagination, 1920-1950, New Haven, CT: Yale University Press, 2005. For a brief survey of aviation and popular culture consult A. Bowdoin Van Ripper, Imagining Flight: Aviation and Popular Culture, College Station: Texas A\&M University Press, 2004.

34 See Film and Filming, 331, April 1982. Also see Don Dwiggins, Hollywood Pilot: A Biography of Paul Mantz, New York, 1967.

35 Branden Hookway, "Cockpit” in Beatriz Colomina, Annemarie Brennan, and Jeannie Kim, Eds., Cold War Hothouses, New York: Princeton Architectural Press, 2004, p. 26. Also see Tom Vanderbilt, Survival City: Adventures among the Ruins of Atomic America, Chicago: University of Chicago Press, 2010, for a 
fascinating study of the material and architectural detritus of the Cold War, including abandoned and junked airplanes, bomb shelters, and missile silos. For how Americans came to view air power as a savior see Steve Call, Selling Air Power: Military Aviation and American Popular Culture after World War II, College Station: Texas A\&M University Press, 2009.

${ }^{36}$ Fried, p. 89.

${ }^{37}$ Wheeler Winston Dixon, Lost in the Fifties: Recovering Phantom Hollywood, Carbondale, IL: Southern Illinois University Press, 2005, p. 178.

${ }^{38}$ Roberts and Olson, p. 351.

${ }^{39}$ Robinson, p. 171.

${ }^{40}$ Emmanuel Levy, Jet Pilot.

${ }^{41}$ Baxter, p. 165.

${ }^{42}$ Ibid.

${ }^{43}$ Roberts and Olson, pp. 351-352.

${ }^{44}$ Hefner quoted by Beatriz Preciado, "Pronotopia" in Cold War Hothouses, , p. 233.

${ }^{45}$ Watts, Mr. Playboy, pp. 137-138.

${ }^{46}$ Levy, Jet Pilot. .

${ }^{47}$ Darryl Jones, Elizabeth McCarthy, and Bernice M. Murphy, Eds., It Came from the 1950s, Popular Culture, Popular Anxieties, New York: Palgrave Macmillan, 2011, pp. 24-25.

${ }^{48}$ Shaw, p. 302.

${ }^{49}$ See Shaw for a discussion of the Cold War films of the 1960s, 70s, and 80s. The old romance/defection trope returns with the The Girl From Petrovka, (1974). For an account of the Reagan years see, Ron Briley, "The Persistence of a Nuclear Threat: Testament (1983) and Red Dawn (1984) as Cultural Narratives of the Reagan Years", Popular Culture Review, Vol. 19, No. 1, Winter 2008, pp. 5-18.

${ }^{50}$ Anderson, "Communist Plot".

${ }^{51}$ Croce, p. 1.

${ }^{52}$ Mark A. Hasan, pp. 1-2. 